UDC 364-7

DOI: https://doi.org/10.17721/2616-7786.2019/5-1/5

A. Shubchynska, Masters Degree ORCID iD 0000-0002-7755-5341

L. Lytva, Ph.D. in Sociology, Associate Professor ORCID iD 0000-0001-9381-2654

Taras Shevchenko National University of Kyiv, Kyiv, Ukraine

\title{
SOCIAL WELFARE AND FAMILY SUPPORT AS A DIRECTION OF HUNGARIAN SOCIAL POLICY
}

The author investigates the transformation processes of family values, preconditions that have influenced the emergence of the familism in Hungarian society. The article deals with the analysis of the main characteristics of neo-familism as the dominant social phenomenon of the present, which directly impacts the Hungarian family policy and determines the further direction of the family support system formation. It has been noted that familism is a complex concept and can be interpreted from different perspectives. This term is revealed through the prism of personal and family values, norms, interpersonal and social relations, as well as governance systems strategies. In this article, familism is discussed mainly as a system of governance measures, disclosed through the demonstration of social, in particular, family policy strategies, as well as instruments of its regulation. Hungarian family policy and the effects of familism on it are described and analysed in several characteristics, such as types of financial support, supporting measures to facilitate parents' participation in the labour market and the social services systems. It is proved that, in comparison with other European Union countries, the parental support system of childcare in Hungary is one of the most comprehensive. On the basis of the analysis, it has been concluded that the Hungarian family support system was formed under the influence of the consequences of historical events and political ideologies. The key factors, which are determining the direction of the system transformation today, are both post-socialism and Europeanisation at the same time. The analysis of the historical preconditions of the family policy formation and its modern regulatory instruments classifies the Hungarian support system as optional familism, which provides universal financial support to families, a comprehensive system of parental leave and childcare allowances, tax deductions, public nursery and kindergarten services. The author also underlines the significance of analysing the Hungarian welfare system and social services which support not only families in difficult life circumstances but also middle-class families.

Keywords: familism, familisation, neo-familism, family policy, family support system, family values, family values transformation.

Introduction. Over the past half-century, we have seen tremendous changes in family systems under the influence of economic development, technological change and cultural transformation. Nowadays, European countries demonstrate several varied concepts regarding the historical development of family policy, institutional structure and legal base. Hungary is a Central European country with actively developing welfare system, besides due to historical and political background has been recognized as a region that has undergone particularly severe socio-political and economic changes. Hungary has completed several stages of reconciliation with European politics and values, but at the same time it is one of the most conservative countries in relation to traditional family values.

Nowadays, the Hungarian family support system provides a wide range of public social services and benefits to families in order to strengthen the family position, involving parents in the labour market and increase the fertility rate, which indicates a strong process of social policy familisation. Therefore, it is important to analyse the Hungarian family policy tools to identify the best practices that could potentially address the current demographic and welfare challenges not only in Hungary but also in all European countries.

Analysis of recent researches and publications shows that there are several approaches to the interpretation of the familism. Some approaches (Garzyn, 2000; Steidel and Contreras, 2003; Campos, Perez and Guardino, 2014) reveal this concept through the definition of family and personal values when other approaches describe it in terms of social organization and social order (Leitner 2003; Oesch, 2011). Nevertheless,these studies refer to obsolete familism concepts that do not reflect entirely its characteristics in the modern perspective. The family values transformation and dynamic of familism ideology in the framework of Hungarian social policy are represented in the studies of Michoc (2008) Robila, (2009), Duman and Horvath (2013), Dupcsik and Tyth (2015) but due to the implementation of new pro-family policy in 2019 the determination of familisation process has to be revised. Family support systems in Hungary are broadly described
bySzikra (2014), Makay (2014), Polese, Morris and Kovбcs (2015), Таkбcs (2017) but the impact of neo-familism on the Hungarian family policy implementation is not comprehensively described, which determines the relevance of this study.

The purpose of the research - to reveal the peculiarities of familism phenomenon and its influence on Hungarian family policy and family support system.

The tasks of the study are to:

- determine the preconditions for the formation and transformation of the familism concept in Hungary as a post-Socialist country.

- identify the main features of familism and its influence on family values and family policy of Hungary.

- analyse Hungarian family support systems from the perspective of the impact of familism ideology on it.

The historical review. As a result of the First and Second World Wars and the fall of Communism, Eastern Europe was characterized by extremely dynamic geopolitical changes during the 20th century. In this part of Europe, the ideas of communism began to spread actively, and the regions and countries that were a part of the Soviet Union were most affected by it.For several decades, the Soviet system has had an impact both on the entire society and family as a fundamental unit of this society. Family habitus and values were mainly controlled by the government, and its priority was a traditional nuclear family, where a woman, as well as a man, was involved in the labour market. In the area of state concern where the practice of raising children, economic strategies related to work and household running, as well as reproductive behaviour (Robila, 2009).

The place and role of the state in the family institution has also been demonstrated in another aspect. During the Soviet period, families were able to rely on public resources in regard to social guarantees and family policy generally. This implied that the government provided them with health care, housing, childcare, various benefits and basic services. But soon families faced the problem of reduced state support, which became targeted and minimal, and thus the responsibility for family well-being was transferred directly to 
families and employers. The crisis of former system has caused unemployment, poverty and demographic problems (Hantrais, 2004; Bari and Rybert, 2016).

Despite the fact that already in 2004 Hungary was preparing for membership with the European Union, the country did not have enough resources to implement appropriate family policy. Hungary was still focused on targeted family policies, while the European strategy included a delegation of responsibility for family welfare to local authorities, the private sector and initiatives. And notwithstanding the current European membership, the country has persistently prioritized traditional family values and the revival of moral values (Hantrais, 2004; Robila, 2009).

Transformation of family values and familism. Hungary is taking the middle position between Western and Eastern European sides geographically and represents values both of them in terms of the political, cultural and social domain (Dupcsik and Tyth, 2015). Besides, Hungary is at a crossroads between Europeanisation and conservatism in terms of preserving traditional family values. To a large extent, these two perspectives do not contradict each other but make different adjustments to the family policy development. The process of reconciliation between Hungarian and European politics began in the 1990s. Initially, it had episodic nature, but as early as 2004 , the principles and basic values of the European Union became important guidelines in the Hungarian political processes. However, compared to other transition countries, the comprehensive family policy system has remained stable and has changed relatively little. In Hungary nowadays, women are primarily responsible for household activities and the role of the mother is given priority over the role of the breadwinner. Nevertheless, families are entitled to various forms of support and services from the state which means that family policy aims to ensure a balance between work and family life. Such strategy indicates Hungarian family welfare as optional familism (Duman and Horvath, 2013).

A literature analysis allows to assume that familism is an extremely complex concept which can be determined and interpreted in distinct ways. The term familism (or familialism) can be viewed from different perspectives as an ideology, system of values, norms, attitudes, social organization and social relations or social order (Garzyn, 2000).

The research of the familism phenomenon dates back to the middle of the $20^{\text {th }}$ century (Mucchi-Faina, Pacilli and Verma, 2010). Early on, the term familism referred to a model of social organisation, based on the prevalence of the family group and its well-being placed against the interests and necessities of each one of its members. It is also a part of the traditional view of society that highlights loyalty, trust, and cooperative attitudes within the family group (Garzyn, 2000). Besides, familism was characterised as a strong identification with family and privilege of loyalty, reciprocity and solidarity among family members (Campos, Perez and Guardino, 2014). There is another definition that corresponds to the previous one and identifies it as the defence of the family as an institution and is implying a belief in the primacy of family affiliation over individual dynamics (Revillard, 2007).

One of the modern perspectives describes familism as a social order aspect and assumes that family have the greatest welfare responsibility towards its members, both in income distribution and care provision. In regard to such interpretation, familialism is the extent to which families are expected to absorb social risk relative to the state (Oesch, 2011).

It is also possible to reveal the concepts of familism through the perspective of its dimensions. Thus, familism comprises 4 elements: priority of the family over its individuals, familial interconnectedness, familial reciprocity and familial honour which means the behaviour of each family member is a determinant that might affect the family as a whole in one way or another (Steidel and Contreras, 2003).

Despite the similarities between above-mentioned concepts, the familism varies from country to country and consequently can be implemented in different ways. Based on the characteristics of different family support tools, four types of familism are distinguished: the optional familialism, the explicit familialism the implicit familialism and defamilialism (Leitner 2003, figure 1). In turn, the term familisation as a process refers to retention of care within the family, or policies that support care performed by family members (Saraceno, 2016).

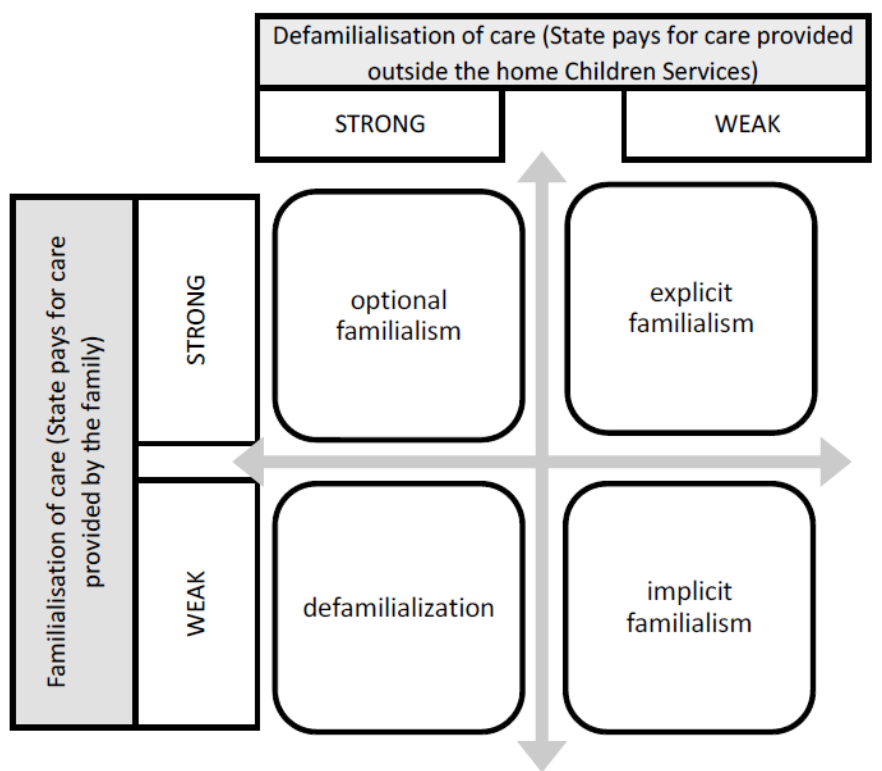

Fig. 1. The Four Types of Policies Distinguished by Leitner

Today, familism in defining family values is one of the strongest and most controversial trends in Hungary. On the one hand, the process of pluralization of family forms in
Hungary began at the end of the $20^{\text {th }}$ century and continues to this day. On the other hand, Hungary is one of the countries where the population supports the traditional 
views in relation to the role of men, women and the family as a whole (Dupcsik and Tyth, 2015).

The ideal image of the family within the framework of familism is a traditional patriarchal stable family with a strong emotional connection, consisting of a married couple with children. Gender roles are clearly defined: the role of the husband is the head of the family and his main functional role is to ensure stability, and the duties of the wife include the household. However, the role of woman in Hungarian society departs from this concept. Historically they have been more active members of the labour market, as well as Europeanization that has amended the family and gender policy of Hungary. Nevertheless, the image of the traditional familism is not only utopian but also an evident reality - this concept widespread in almost all spheres of the Hungarian political spectrum. The Hungarian old constitution has been changed several times. After last modifying ruling cabinet laid down the conservative ideological foundations which promotes the traditional family ideology and increase of fertility rates among middle-class families (Bari and Rybert, 2016; Szikra, 2018).

According to The Fundamental Law of Hungary 2018 , the family constitute is a priority and the principal framework of Hungarian coexistence, thus Hungarian government is responsible for the protection of the institution of marriage as the union of a man and a woman. Furthermore, family ties are based on marriage or the relationship between parents and children, hence Hungary supports the commitment to have children. This undoubtedly indicates a high level of state intervention in the family institution and traditional family values promotion (Dupcsik and Tyth, 2015). At the same time, families with unstable labour market positions are not sufficiently supported by family policy. Thus, the family support system focuses on "working" families and aims to strengthen a positive image of the family. Families in difficult circumstances are increasingly excluded from family policy and can receive only limited social support (Szikra, 2018).

The Hungarian family support system. The family support system may include different tools such as financial initiatives, various support mechanisms for parents to combine work and family as well as broad social change supportive of children and parenting. In the framework of this research Hungarian financial initiatives, the support system for employed and unemployed parents and social services as main dimensions of familism measurement will be reviewed (S6gi, Lentner and Tatay, 2018).

As mentioned previously, one of the most important characteristics of modern familism in the family support system framework is large variations of state benefits to families and especially to women to facilitate the combination of paid work and family. Apparently, the aim of such a strategy is to reduce the financial burden for families with children by providing in-kind and financial support as predominant family support tools (Olбh, 2015).In Hungary, family policy plays a central role in politics which is clearly the concern of the state. Hence the Hungarian family benefits system includes approximately 20 varied types of benefits. Among them are wide range of financial allowances, tax reduction and loans which are primarily available to families with children and considered as one of the most evidential indicators of strong familisation(Makay, 2014).

As illustrated in figure 2, the Hungarian system of family benefits counts as quite generous in comparison with other European countries, and the existence of three different family support schemes for caring for children at home is unique in Europe (OECD Social Expenditure Database 2019, figure 2). Hungarian government provides the following benefits to support families with children: maternity grant, baby-care allowance, childcare allowance and childcare benefit, as well as a family allowance (childrearing allowance and the schooling support) and childrearing support (Makay, 2014).

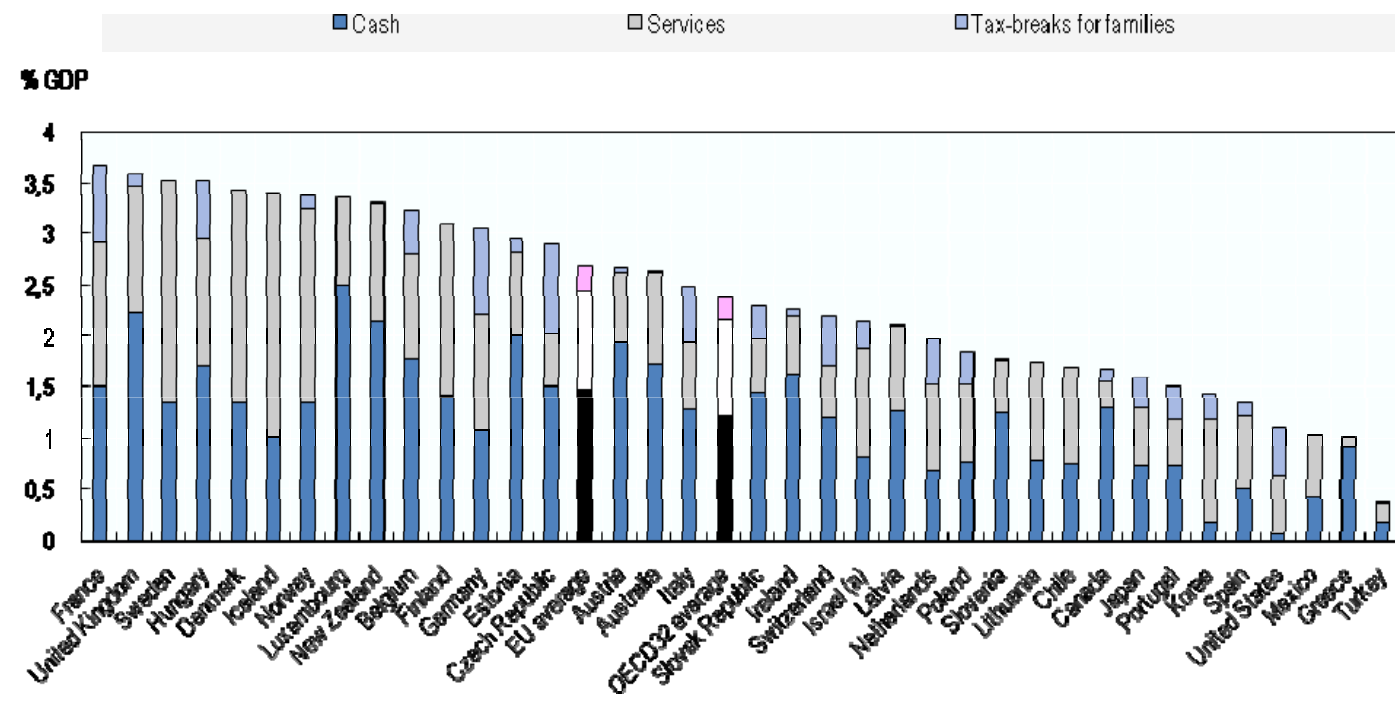

Fig. 2. Public spending on family benefits by type of expenditure, in percent of GDP, 2015 and latest available

To take care of newborn child parents are entitled to 6 months of maternity and parental leave. During maternity leave family can receive baby-care allowance(CSED) that covers $70 \%$ of the previous average earnings of a mother (with no ceiling on payments) and gives opportunity to mother to work up to 3 hours daily. In the same time, family can use parental leave with equal funding as CSED, which is provided to the father to stay at home for 5 days of allocated time within two months following the date of birth. After the end of the $24^{\text {th }}$ week maternity leave, baby-care allowance stops and parents can claim childcare benefit (GYED), which can last until the second birthday of child. GYED benefit includes $70 \%$ of average daily earnings and has an upper limit at $70 \%$ of twice the amount of the minimum wage (HUF 208,600 [UAH 16 445] per month). The big advantage for the family is the possibility for parent who useGYED to work 
unlimited hours after the child becomes 6 months old and receive the full benefit until the child becomes 2 years old. Nevertheless, only one parent at a time can take GYED. Non-insured parents are entitled to receive childcare allowance (GYES) from birth until the age of three. Insured parents, who receive GYED, after the end of payment period can claim childcare allowance as well. In both cases it is a universal benefit with fixed-sum payment equal to the statutory minimum amount of old-age pension (HUF 28,500 [UAH 2 246] per month).Equally to the GYED, the employed mother is entitled to work regular hours after the child turns 6 months old (Makay, 2014; G6bos, 2017).

Besides the above-mentioned benefits, women who attended prenatal care at least four times during their pregnancy are entitled to a one-off payment after childbirth (maternity grant) with an amount of HUF 64,125 [UAH 5 053] in 2019. As previously stated, the Hungarian government provides a family allowance. This kind of allowance includes monthly payment for children from birth to the period of time when they finish their education (but no later than 20). Thus, families are entitled HUF 12,200 [UAH 961] for one child, HUF 13,300 [UAH 1 048] per child if there are two children, and HUF 16,000 [UAH 1260 ]per child in case of three or more children (Gбbos, 2017).

There is another benefit for parents which reduces family taxes (individually or together) depends on the number of children in a family. For case, if a family has one child, personal income tax base can be reduced by HUF 66,670 [UAH 5 254] per month. Parents also can use family tax relief benefit from the third month of pregnancy. In addition to this, when the number of children in a family grows, any of the above-mentioned benefits increase as well.Furthermore, government providenewlywed allowance for newly married first-time couples which gives them opportunity to reduce their tax base for 24 months after the wedding (Makay, 2014).

The other side of this financial support and the opportunity to raise a child for several years has an undesirable effect - a decrease in the employment rate of women since they leave the labour market for years to look after their children at home. In Hungary, the state tries to increase female employment rates by providing nursery, daycare centres and kindergarten services, to ensure that women with children can work. There are three types of childcare services for children: nursery under the age of three, family day-care caters and childminders. Nursery and day-care services can be reimbursed in the form of a tax reduction or as an invoice. However, about $90 \%$ of children under 3 years of age are at home in the care of their parents, and only a few per cent use the services of the centres, primarily nurseries (Makay, 2014).

At the beginning of 2019, a new approach to strengthening the position of families in Hungary was announced. Nowadays, the pro-family policy provides seven points of the family support package: interest-free (all-purpose) loan, housing benefits, mortgage deductions, exemption from personal income tax, car purchase program, improved nursery service and childcare allowance for grandparents (S6gi, Lentner and Tatay, 2018).

All-purpose loans give opportunities to married and employed woman aged 14 to 40 to apply for an interestfree loan of 10 million HUF [UAH 787,460]. Loan repayment may be suspended for 3 years from the birth of the first child. If the second child is born, the loan is cancelled by $30 \%$. In the case of the birth of a third child, the debt is fully repaid by the state. Hungary's family homeownership subsidy program (CSOK) includes financial benefits for families with 2 or 3 children to purchase used or newly built homes. Currently, the grant amount is 10 and 15 million HUF accordingly to aforementioned requirements. Furthermore, the government deducts from the loan 1 million HUF for the second child and 4 million HUF for the third born child and for every next child the government repays the loan by 1 million HUF additionally. In addition to the previously described tax reduction mechanisms, the Hungarian government exempts women with four or more children from paying taxes. In terms of such exemption this benefit is available not only for families with little kids (below the age of 18) but also for families with adult children (Sбgi, Lentner and Tatay, 2018). In accordance to car purchasing programs, families with three or more children can apply for non-repayable financial grant (The 2.5 million HUF) to purchase a new, 7-seater car.Alongside, as a part of the new Hungarian pro-family policy strategy the government will provide 21,000 nursery places over the next three years to involve woman to the labour market (currently available 50,000 places).

Conclusion. The family institution and consequently family policy are constantly being transformed under the influence of social and economic conditions. Hungary belongs to the countries of late modernization and is currently at the stage of active family policy development. Due to the influence of the Soviet regime, the country has inherited the familism ideology, but it has been transformed over time, along with family values, into the concept of neofamilism. Unlike former familism, which emphasizes the clear dominance of family interests over individual interests, neo-familism promotes a combination of individual rights and family responsibilities and seeks to strike a balance between family and individual. An important feature of neo-familism is to raise the issue of increasing the employment rate of women, while at the same time encouraging the prolonged childrearing. Hungarian family support actively aims at strengthening the family and includes such tools as time rights (parental leave system), direct and indirect transfers for caring (e.g. tax reductions and cash benefits) as well as social rights attached to caregiving. Thus, Hungary can be classified as a model of optional familialism in terms of its universal family allowances, comprehensive system of paid parental leaves, tax allowances, extensive coverage of public nurseries and kindergarten.

Nevertheless, Hungarian familialistic policies have not had the same effect on all strata of the society since most of the state benefits are focused on capable families in terms of employment, income stability and abilities of families to pay relevant taxes. Furthermore, women who receive maternity and parental benefits based on their previous income (GYED) have higher allowance than other women with a flat-rate parental leave which is only slightly above the minimum wage. As a result, despite the wide range of services and benefits, families in difficult circumstances are excluded from the support system. On the other hand, such a system motivates families to strengthen their position in the labour market and at the same time to receive substantial comprehensive support from the state. This kind of family policy demonstrates a new focus on family work and the instruments of family policy, which is aimed not only at supporting families in difficult circumstances but also middle-class families.

Perspectives of further research.At the stage of active familyinstitution transformation and family support system development in Ukraine, it is significant to analyse the best international experience of the family policy implementation, as well as take into consideration successful Ukrainian practices in such field. This article provides only an overview of the Hungarian family policy and its regulation tools. Therefore, it is important to perform an extended comparative study with the use of wide-range dimensions, conduct an expert study and build a modelsuggestion for the development of the family support system in Ukraine. 
References

1. Bari, D., Rybert, P. (2016). Who Benefits More from a Balanced life? Gender Differences in Work-life Balance and Satisfaction with Life in Eight Post-communist Countries. Intersections, 2(3). - P. 21-41.

2. Campos, B., Perez, O., Guardino, C. (2014). Familism. Journal of Social and Personal Relationships, 33(1). - P. 81-100.

3. Duman, A., Horvath, A. (2013). Traditional Familialism Served with EU Gravy. Politique europǔenne, 40(2). - P. 22.

4. Dupcsik, C., Tyth, O. (2015). Family Systems and Family Values in Twenty-First-Century Hungary. Family and Social Change in Socialist and Post-Socialist Societies. - P. 210-249.

5. Gábos, A. (2017). Hungary country note. [ebook] Budapest: International Review of Leave Policies and Research 2017. - P. 1-7. Available at: http://www.leavenetwork.org/lp_and_r_reports/ [Accessed 29 Nov. 2019].

6. Garzyn, A. (2000). Cultural change and familism. Psycothema, 12. P. 45-54.

7. Hantrais, L. (2004). Family policy matters. Bristol: Policy Press. P. 163-190.

8. Leitner, S. (2003). Varieties of familialism: The caring function of the family in comparative perspective. European Societies, 5(4). - P. 353-375.

9. Makay, Z. (2014). Demographic Portrait of Hungary 2015. Budapest: Hungarian Demographic Research Institute. - P. 57-74

10. Mucchi-Faina, A., Pacilli, M. and Verma, J. (2010). The Two Faces of Familism: A Cross-Cultural Research in India and Italy. Psychological Studies, 55(4). - P. 365-373.

11. OECD Social Expenditure Database 2019, Public spending on family benefits 2015, OECD Social Expenditure Database viewed, 11 November 2019: https://www.oecd.org/social/expenditure.htm>.

12. Oesch, D. (2011). Gosta Esping-Andersen: The Incomplete Revolution: Adapting to Women's New Roles. European Sociological Review, 27(2). - P. 288-290.

\section{А. Шубчинська магістр}

ORCID iD 0000-0002-7755-5341

Л. Литва, канд. соціол. наук, доц.

ORCID iD 0000-0001-9381-2654

Київський національний університет імені Тараса Шевченка, Київ, Україна
13. Oláh, L. Sz. (2015). Changing families in the European Union: trends and policy implications. Families And Societies - Changing families and sustainable societies: Policy contexts and diversity over the life course and across generations. - № 44. - P. 2-24.

14. Polese, A., Morris, J. and Kov6cs, B. (2015). Introduction: The Failure and Future of the Welfare State in Post-socialism. Journal of Eurasian Studies, [online] 6(1). - P. 1-5. Available at: http://www.elsevier.com/ locate/euras [Accessed 14 Oct. 2019].

15. Revillard, A. (2007). Stating Family Values and Women's Rights: Familialism and Feminism Within the French Republic. French Politics. - № 5(3). - P. $210-228$

16. Robila, M. (2009). Families in Eastern Europe. Bingley: Emerald Group Publishing Limited. - P. 1-4.

17. Sági, J., Lentner, C. and Tatay, T. (2018). Family Allowance Issues. Polgбri szemle, 14 (Special Issue). - P. 290-301.

18. Saraceno, C. (2016). Varieties of familialism: Comparing four southern European and East Asian welfare regimes. Journal of European Social Policy, 26(4). - P. 314-326.

19. Steidel, A. and Contreras, J. (2003). A New Familism Scale for Use with Latino Populations. Hispanic Journal of Behavioral Sciences. - № 25(3). - P. 312-330.

20. Szikra D. (2018). Welfare for the wealthy. The social policy of the Orbбn-regime, 2010-2017, FES Analysis March 2018, Budapest : FriedrichEbert-Stiftung. - P. 2-10.

21. Szikra, D. (2014). Democracy and welfare in hard times: The social policy of the Orbбn Government in Hungary between 2010 and 2014. Journal of European Social Policy. - № 24(5). - P. 486-500.

22. Takács, E. (2017). Changing family - changing solidarity? The phenomenon of family solidarity. Review of Sociology. № 27(4). - P. 5-19.

Received June 11,2019

Reviewed June 25, 2019

\section{СОЦІАЛЬНИЙ ЗАХИСТ І ПІДТРИМКА СІМЕЙ ЯК НАПРЯМОК СОЦІАЛЬНОї ПОЛІТИКИ УГОРЩИНИ}

Досліджуються проблеми трансформації сімейних цінностей, визначаються передумови виникнення феномена фамілізму та його вплив на суспільство в Угорщині. Розглядаються головні характеристики неофамілізму як домінантного соціального явища сучасновплив на суспільство в Угорщині. Розглядаються головні характеристики неофамілізму як домінантного соціального явища сучаснозначено, що фаміліям - це комплексний концепт, який може інтерпретуватися з різних перспектив. Дане поняття розкривається через призму особистісних і сімейних цінностей, норм, міжособистісних і суспільних відносин, а також стратегій систем управління. У даній статті фаміліям розглядається переважно як система управлінських заходів, розкривається через презентацію стратегій соціальної, зокрема сімейної політики, а також інструментів їі регулювання. Сімейна політика Угорщини та наслідки впливу на неї фамілізму описано та проаналізовано за кількома характеристиками, таким як: види фінансової підтримки, заходи щодо сприяння батькам в їхній участі на ринку праці та системи соціальних послуг. Було підтверджено, що порівняно з іншими країнами Євросоюзу ситькам в їхній участі на ринку праці та системи соціальних послуг. Було підтверджено, що порівняно з іншими країнами Євросоюзу висновок, що система підтримки сімей Угорщини була сформована під впливом наслідків історичних подій і політичних ідеологій. Ключовими факторами, які визначають напрям трансформації такої системи сьогодні залишаються як постсоціалізм, так $і$ європеїзація одночасно. Аналіз історичних передумов формування сімейної політики та їі сучасних інструментів регулювання, класифікує угорську систему підтримки як опціональний фамілізм, який передбачає надання сім'ям фінансової підтримки, комплексну систему відпусток при народженні та за доглядом за дитиною, податкові відрахування, послуги державних ясел і дитячих садків. Автор також підкреслює важливість аналізу угорської системи соціального захисту і соціальних послуг, які підтримують як сім'і у складних життєвих обставинах, так і сім'і середнього класу.

Ключові слова:фамілізм, фамілізація, неофамілізм, сімейна політика, система підтримки сімей, сімейні цінності, трансформація сімейних цінностей.

А. Шубчинская, магистр

ORCID iD 0000-0002-7755-5341

Л. Литва, канд. социол. наук, доц.

ORCID iD 0000-0001-9381-2654

Киевский национальный университет имени Тараса Шевченко, Киев, Украина

\section{СОЦИАЛЬНАЯ ЗАЩИТА И ПОДДЕРЖКА СЕМЬИ КАК НАПРАВЛЕНИЕ СОЦИАЛЬНОЙ ПОЛИТИКИ ВЕНГРИИ}

Исследуются проблемы трансформации семейных ценностей, определяются предпосылки возникновения феномена фрамилизма и его влияние на общество в Венгрии. Рассматриваются главные характеристики неофамилизма как доминирующего социального явления современности, которое оказывет непосредственное влияние на венеерскую семейную политику и определяет дальнейшее явления современности, которое оказывет непосредственное влияние на венгерскую семейную политику и определяет дальнейшее семей и социальных услуд, которые охватывают не только семьи, находящихся в трудных жизненных обстоятельствах, но и семьи среднего класса.

Ключевые слова: фамилизм, фамилизация, неофамилизм, семейная политика, система поддержки семей, семейные ценности, трансформация семейных ценностей. 